\title{
KEARIFAN BUDAYA LOKAL MASYARAKAT MARITIM UNTUK UPAYA MITIGASI BENCANA DI SUMATERA BARAT ${ }^{1}$
}

\author{
Lucky Zamzami² Hendrawati ${ }^{3}$
}

\begin{abstract}
Local wisdom that exists in the community is potentially a very valuable in dealing with the problems of natural disasters that hit the region. Understanding of the potential of local wisdom in dealing with the threat of natural disasters is important in disaster mitigation efforts in disaster-prone areas. One of the natural disaster-prone areas in West Sumatra that have the potential of local cultural wisdom is Ulakan Nagari, Kec. Ulakan Tapakis, Kab. Padang Pariaman. This region includes the areas worst affected by the earthquake last 30 September 2009. However, these communities do not get a lot of casualties caused by the earthquake

The power of religion as a major potential cultural wisdom of this community, namely the existence of the tomb of the great scholar Shaykh Burhanuddin considered believed society could reject any disaster so that when disaster strikes, the community has a great power to anticipate the disaster. The community did with various religious traditions, such as dhikr (prayer) in the tomb and on the waterfront and implement indigenous tradition (sort of ceremony Tabuik) as a sign of gratitude to Allah SWT. Besides the religious aspect, the public trust with marine geography which has the power of a tsunami hazard barrier so that people believe that the tsunami would not harm them.
\end{abstract}

Keywords: Local Wisdom, Natural Disaster, Fishermen Community, Disaster Mitigation

I. Pendahuluan

1.1 Latar Belakang

Decara geografis Indonesia

merupakan negara kepulauan yang terletak pada pertemuan empat lempeng tektonik, yaitu lempeng Benua Asia, Benua Australia, lempeng Samudera Hindia dan Samudera Pasifik. Pada bagian Selatan dan timur Indonesia terdapat sabuk vulkanik (vulkanic arc) yang memanjang dari Pulau SumateraJawa-Nusa Tenggara-Sulawesi, yang sisinya berupa pegunungan vulkanik tua dan dataran rendah yang sebagian besar didominasi oleh rawa-rawa. Kondisi tersebut sangat berpotensi sekaligus rawan bencana seperti letusan gunung berapi, gempa bumi, tsunami, banjir dan tanah longsor. Data menunjukkan bahwa Indonesia merupakan salah satu negara yang memiliki tingkat kegempaan yang tinggi di dunia, lebih dari 10 kali lipat tingkat kegempaan di Amerika Serikat (Bappenas, 2006: 1-2)

Kejadian bencana di Indonesia terus meningkat dari tahun ke tahun. Data bencana dari Bakornas PB menyebutkan bahwa antara tahun 2003-2006 telah

\footnotetext{
${ }^{1}$ Artikel ini merupakan hasil penelitian Dosen Muda yang dibiayai oleh Lembaga Penelitian Unand tahun 2011

${ }^{2}$ Penulis adalah dosen tetap jurusan Antropologi FISIP Universitas Andalas, Padang

${ }^{3}$ Penulis adalah dosen tetap jurusan Antropologi FISIP Universitas Andalas, Padang
} 
terjadi 1.429 kejadian bencana, dimana bencana hidrometeorologi merupakan bencana yang paling sering terjadi, yaitu 53.3 persen dari total kejadian bencana di Indonesia. Dari total bencana hidrometeorologi, yang paling sering terjadi adalah banjir (34.1\%), diikuti oleh tanah longsor (16\%). Meskipun frekuensi bencana geologi (gempa bumi, tsunami dan letusan gunung berapi) hanya $6.4 \%$, bencana ini telah menimbulkan kerusakan dan korban jiwa yang besar, terutama akibat gempa bumi yang diikuti tsunami di propinsi NAD dan Sumatera Utara tanggal 24 Desember 2004 dan gempa bumi besar yang melanda Pulau Nias pada tanggal 28 Maret 2005 (Bappenas, 2006: $3)$.

Wilayah pantai di Indonesia merupakan wilayah yang rawan terjadi bencana terutama di wilayah pantai Barat Sumatera dan tentunya sangat mempengaruhi kepada keberadaan masyarakat yang mendiami wilayah pantai tersebut, yaitu masyarakat nelayan. Dengan kondisi potensi sumberdaya alam pesisir dan laut, dewasa ini sudah semakin disadari banyak orang bahwa sumberdaya ini merupakan suatu potensi yang cukup menjanjikan dalam mendukung tingkat perekonomian masyarakat terutama bagi nelayan. Konsekuensi logis dari sumberdaya pesisir dan laut sebagai sumberdaya milik bersama (common property) dan terbuka untuk umum (open acces) maka pemanfaatan sumberdaya alam pesisir dan laut dewasa ini semakin meningkat di hampir semua wilayah.

Namun demikian dengan kondisi rawan bencana di wilayah pesisir pantai tersebut menyebabkan potensi sumberdaya alam pesisir dan laut tidak bisa dikelola secara maksimal. Hal ini juga didukung oleh kondisi masyarakat nelayan yang bercirikan tradisional kurang berorientasi kepada masa depan, penggunaan teknologi masih sederhana, kurang rasional, relatif tertutup terhadap orang luar, dan kurang berempati. Mereka masih melaksanakan kegiatan di laut secara tradisional, seperti menangkap ikan dengan jala, pancing dan lainnya sehingga secara ekonomi mereka masih kurang beruntung, padahal kalau dilihat dari hasil penangkapan di laut secara keseluruhan sangat banyak (Zamzami, 2009:72)

Ancaman bencana terhadap masyarakat nelayan tersebut dapat terjadi secara tiba-tiba atau pun melalui proses yang perlahan-lahan. Bencana merupakan suatu gangguan yang serius terhadap keberfungsian suatu masyarakat sehingga menyebabkan kerugian yang meluas pada kehidupan manusia, baik dari segi tatanan ekonomi, sosial maupun lingkungan. Bencana alam dirasakan sebagai sumber malapetaka, di saat menimpa tempat yang banyak penduduknya sehingga bencana banyak menimbulkan penderitaan dan kerugian. Dengan berbagai bencana tersebut, maka muncullah pengelolaan penanganan bencana yang disebut dengan Mitigasi Bencana.

Mitigasi bencana adalah salah satu cara atau tindakan untuk mengurangi supaya kerugian dapat diperkecil. Menurut Keputusan Menteri Dalam Negeri RI No. 131 tahun 2003, bahwa mitigasi adalah upaya yang dilakukan untuk mengurangi akibat-akibat yang ditimbulkan oleh bencana yang meliputi kesiapsiagaan dan kewaspadaan. Namun demikian, mitigasi bencana tersebut belum dijadikan sebagai budaya lokal di dalam masyarakat secara luas. Terlebih lagi kemudian disimpulkan bahwa penyebab tidak optimalnya mitigasi bencana adalah rendahnya pemahaman/pengetahuan masyarakat tersebut (Maryani, 2008:2)

Fenomena di atas menunjukkan bahwa dibutuhkan sebuah model pendekatan yang lebih mengakar dan memberi hasil yang maksimal dalam upaya pembentukan budaya mitigasi bencana di Indonesia. Pendekatan kearifan budaya lokal (Culture local wisdom) sebagai salah satu pendekatan yang pernah sukses dalam masyarakat Aceh di Pulau Simelue dalam membaca fenomena alam pantai yang telah menyelamatkan ribuan masyarakat dari bencana tsunami dan juga terjadi pada penduduk sekitar Gunung Kelud yang melihat tanda-tanda hewan ketika gunung Kelud akan meletus. 


\subsection{Permasalahan}

$\mathrm{K}$

earifan budaya lokal yang ada dalam masyarakat merupakan potensi yang sangat berharga untuk bisa dimanfaatkan dalam menghadapi persoalan-persoalan bencana alam yang selalu melanda suatu wilayah. Bencana alam berupa gempa bumi, tsunami, banjir dan letusan gunung berapi yang sering terjadi belakangan ini harus disikapi secara serius oleh pemerintah. Bencana gempa bumi dan tsunami misalnya telah mengakibatkan kerugian materiil dan non materiil dan bahkan korban jiwa yang sangat besar. Lebih dari $75 \%$ korban meninggal terjadi di kota, yang diakibatkan karena reruntuhan, terbatasnya akses dan ruang evakuasi di perkotaan dan kebakaran pasca gempa terjadi. Kerawanan bencana di Indonesia secara geologis memiliki potensi yang besar, khususnya pada beberapa bagian wilayah dan kota yang berada pada jalur patahan lempeng Eurasian (Asia, Pasifik dan Australia) dan garis circumstance, yaitu garis potensi bencana gunung berapi yang membentang di sepanjang Asis, Pasifik dan Amerika yang melewati daerah Indonesia (Wikantiyoso, 2010:18).

Dalam perspektif kearifan budaya lokal, satwa seperti ikan, buaya, burung, kalong, binatang liar lainnya dan bintangbintang oleh masyarakat tradisional diamati sebagai fenomena alam yang kemudian dijadikan petunjuk baik sebagai tanda-tanda datangnya bencana alam ataupun musim dalam pertanian, seperti masyarakat Jawa tengah mengenai Pranata Mangsa, masyarakat Bali mengenai Kerta Masa, masyarakat Sulawesi Selatan menyebutnya Palontara dan masyarakat Nusa Tenggaran menyebutnya Nyali, dan orang Dayak menyebutnya Bulan Berladang. (Noor dan Jumberi, 2008)

Naiknya ikan-ikan jumlah besar di sekitar pantai Maluku Utara sebuah fenomena alam yang ternyata merupakan pertanda akan terjadinya gempa. Fenomena ini telah diyakini oleh masyarakat Maluku Utara sehingga telah menyelamatkan mereka dari bencana letusan Gunung Kiebesi pada tahun 1988. Demikian juga, tsunami yang memporakporandakan Aceh dan
Sumatera Utara pada bulan Mei 2006 dimana sebelum tsunami terjadi, di atas wilayah Aceh terlihat segerobolan kalong yang sedang melakukan migrasi dan ditemukan bukti bahwa pasca tsunami tidak banyak ditemukan bangkai-bangkai hewan liar (Fauzi, 2006). Dengan demikian pemahaman atas potensipotensi kearifan budaya lokal dalam menghadapi ancaman bencana alam menjadi penting dalam upaya mitigasi bencana di daerah rawan bencana.

Berdasarkan hal tersebut diatas, maka penelitian ini menjawab pertanyaan (research question), yaitu bagaimana karakteristik kebencanaan dan pemahaman masyarakat pesisir pantai di daerah rawan bencana dan juga bagaimana potensi kearifan budaya lokal masyarakat pesisir pantai berkaitan dengan upaya mitigasi bencana dan penanggulangannya.

\subsection{Tujuan}

ujuan dari penelitian ini adalah
untuk mendeksripsikan karakteristik
kebencanaan dan potensi kearifan budaya lokal masyarakat pesisir pantai berkaitan dengan mitigasi bencana, dan untuk menganalisis pemahaman masyarakat pesisir pantai di daerah rawan bencana dan penanggulangannya.

\subsection{Tinjauan Pustaka}

$\mathrm{M}$ anusia mempunyai kapasitas untuk mencerap apa yang terjadi di sekelilingnya, selanjutnya menganalisis dan menafsirkan baik sebagai hasil pengamatan maupun pengalaman, yang pada gilirannya dapat digunakan untuk meramalkan atau pun sebagai dasar pertimbangan dalam pengambilan keputusan. Jadi pengetahuan merupakan keluaran dari proses pembelajaran, penjelasan berdasarkan pemikiran dan persepsi mereka. Menurut Johnson dalam Sunaryo dan Joshi (2003), pengetahuan lokal adalah sekumpulan pengetahuan yang diciptakan oleh sekelompok masyarakat dari generasi ke generasi yang hidup menyatu dan selaras dengan alam, pengetahuan seperti ini berkembang dalam lingkup lokal, 
menyesuaikan dengan kondisi dan kebutuhan masyarakat.

Pengetahuan lokal merupakan konsep yang lebih luas yang merujuk pada pengetahuan yang dimiliki oleh sekelompok orang yang hidup di wilayah tertentu untuk jangka waktu yang lama. Pada pendekatan ini, kita tidak perlu mengetahui apakah masyarakat tersebut penduduk asli atau tidak. Yang jauh lebih penting adalah bagaimana suatu pandangan masyarakat dalam wilayah tertentu dan bagaimana mereka berinteraksi dengan lingkungannya, bukan apakah mereka itu penduduk asli atau tidak. Hal ini penting dalam usaha memobilisasi pengetahuan mereka untuk merancang intervensi yang lebih tepatguna (Noor dan Jumberi, 2008).

Pengetahuan lokal suatu masyarakat seperti petani yang hidup di lingkungan wilayah yang spesifik biasanya diperoleh berdasarkan pengalaman yang diwariskan secara turun temurun. Pengetahuan praktis petani tentang ekosisten lokal, sumber daya alam dan bagaimana mereka saling berinteraksi akan tercermin baik di dalam teknik bertani maupun keterampilan mereka dalam mengelola sumber daya alam. Pengetahuan lokal yang sudah sedemikian menyatu dengan sistem kepercayaan, norma dan budaya diekspresikan di dalam tradisi dan norma yang dianut dalam jangka waktu yang lama inilah disebut dengan kearifan budaya lokal.

Kearifan budaya lokal
sesungguhnya merupakan bagian dari etika dan moralitas yang membantu manusia untuk menjawab pertanyaan moral apa yang harus dilakukan, bagaimana harus bertindak khususnya dibidang pengelolaan lingkungan dan sumberdaya alam. Bahasan ini sangat membantu kita dalam hal mengembangkan perilaku, baik secara individu maupun secara kelompok dalam kaitan dengan lingkungan dan upaya pengelolaan sumberdaya alam. Selain itu membantu kita untuk mengembangkan sistem sosial politik yang ramah terhadap lingkungan serta mengambil keputusan dan kebijakan yang berdampak terhadap lingkungan atau sumberdaya alam termasuk sumberdaya alam pesisir dan laut (Stanis, 2005:24-27).

Pengertian kearifan lokal, menurut Keraf (2002) adalah semua bentuk pengetahuan, keyakinan, pemahaman atau wawasan serta adat kebiasaan atau etika yang menuntun perilaku manusia dalam kehidupan di dalam komunitas ekologis. Dijelaskan pula bahwa kearifan lokal/tradisional bukan hanya menyangkut pengetahuan dan pemahaman masyarakat tentang manusia dan bagaimana relasi yang baik di antara manusia, melainkan juga menyangkut pengetahuan, pemahaman dan adat kebiasaan tentang manusia, alam dan bagaimana relasi di antara penghuni komunitas ekologis ini harus dibangun. Pengertian di atas memberikan cara pandang bahwa manusia sebagai makhluk integral dan merupakan satu kesatuan dari alam semesta serta perilaku penuh tanggung jawab, penuh sikap hormat dan peduli terhadap kelangsungan semua kehidupan di alam semesta serta mengubah cara pandang antroposentrisme ke cara pandang biosentrisme dan ekosentrisme.

Nilai-nilai kerarifan lokal yang terkandung dalam suatu sistem sosial masyarakat, dapat dihayati, dipraktekkan, diajarkan dan diwariskan dari satu generasi ke genarasi lainnya yang sekaligus membentuk dan menuntun pola perilaku manusia sehari-hari, baik terhadap alam maupun terhadap alam. Ataupah (2004), mengatakan bahwa kearifan lokal bersifat histories tetapi positip. Nilai-nilai diambil oleh leluhur dan kemudian diwariskan secara lisan kepada generasi berikutnya lalu oleh ahli warisnya tidak menerimanya secara pasif dapat menambah atau mengurangi dan diolah sehingga apa yang disebut kearifan itu berlaku secara situasional dan tidak dapat dilepaskan dari system lingkungan hidup atau sistem ekologi/ekosistem yang harus dihadapi orang-orang yang memahami dan melaksanakan kearifan itu. Dijelaskan lebih lanjut bahwa kearifan tercermin pada keputusan yang bermutu prima. Tolok ukur suatu keputusan yang bermutu prima adalah keputusan yang diambil oleh seorang tokoh/sejumlah tokoh dengan cara menelusuri berbagai masalah yang berkembang dan dapat 
memahami masalah tersebut. Kemudian diambil keputusan sedemikian rupa sehingga yang terkait dengan keputusan itu akan berupaya melaksanakannya dengan kisaran dari yang menolak keputusan sampai yang benar-benar setuju dengan keputusan tersebut.

Namun demikian, potensi kearifan lokal tersebut tidak akan bisa dikelola apabila dipengaruhi oleh faktor-faktor internal dan eksternak, yaitu (1) kurangnya pemahaman terhadap karakteristik bencana (hazards); (2) sikap dan perilaku yang mengakibatkan rentannya kualitas sumber daya alam (vulnerability); (3) kurangnya informasi peringatan dini sehingga mengakibatkan ketidaksiapan; (4) ketidakberdayaan/ ketidakmampuan dalam menghadapi bahaya. Karena itu perlu diupayakan program yang praktis namun sistematis dalam memberikan pemahaman karakteristik bencana, yaitu usaha mitigasi bencana (Maryani, 2009).

Usaha mitigasi dapat berupa prabencana, saat bencana dan pasca bencana. Prabencana berupa kesiapsiagaan atau upaya pemberdayaan dengan memberikan pemahaman kepada masyarakat untuk mengantisipasi bencana melalui pemberian informasi, peningkatan kesiagaan kalau terjadi bencana, ada langkah-langkah untuk memperkecil resiko bencana. Pada saat kejadian berupa tanggap darurat yaitu upaya yang dilakukan segera pada saat kejadian bencana untuk menanggulangi dampak yang ditimbulkan, terutama berupa penyelamatan korban, harta benda, evakuasi dan pengungsian. Pasca bencana berupa pemulihan rehabilitasi dan pembangunan (Maryani, 2009).

Pemberdayaan masyarakat sebenarnya mengacu pada kata "empowerment " yaitu sebagai upaya untuk mengaktualisasikan potensi yang sudah dimiliki oleh masyarakat. Jadi, pendekatan pemberdayaan masyarakat dalam pengembangan masyarakat pesisir dan nelayan adalah penekanan pada pentingnya masyarakat lokal yang mandiri (selffreliant communities), sebagai suatu sistem yang mengorganisir diri mereka sendiri. Menurut Moebyarto bahwa pendekatan pemberdayaan masyarakat yang demikian tentunya diharapkan memberikan peranan kepada individu bukan sebagai obyek, tetapi sebagai pelaku (aktor) yang menentukan hidup mereka (Wahyono, 2001).

Pendekatan pemberdayaan masyarakat yang berpusat pada manusia (people-centereddevelopment) ini kemudian melandasi wawasan pengelolaan sumberdaya lokal (communitybased management), yang merupakan mekanisme perencanaan people-centered development yang menekankan pada teknologi pembelajaran sosial (social learning) dan strategi perumusan program. Adapun tujuan yang ingin dicapai adalah untuk meningkatkan kemampuan masyarakat dalam mengaktualisasikan dirinya (empowerment). Dalam kaitan ini, Moebyarto mengemukakan ciri-ciri pendekatan pengelolaan sumberdaya lokal yang berbasis masyarakat, yang meliputi:

a. Keputusan dan inisiatip untuk memenuhi kebutuhan masyarakat setempat dibuat di tingkat lokal, oleh masyarakat yang memiliki identitas yang diakui peranannya sebagai partisipan dalam proses pengambilan keputusan.

b. Fokus utama pengelolaan sumberdaya lokal adalah memperkuat kemampuan masyarakat miskin dalam mengarahkan asset-asset yang ada dalam mayarakat setempat, untuk memenuhi kebutuhannya.

c. Toleransi yang besar terhadap adanya variasi. Oleh karena itu mengakui makna pilihan individual, dan mengakui proses pengambilan keputusan yang desentralistis.

d. Budaya kelembagaannya ditandai oleh adanya organisasi-organisasi yang otonom dan mandiri, yang saling berinteraksi memberikan umpan balik pelaksanaan untuk mengoreksi diri pada setiap jenjang organisasi.

e. Adanya jaringan koalisi dan komunikasi antara pelaku dan organisasi lokal yang otonom dan mandiri, yang mencakup kelompok penerima manfaat, pemerintah lokal, bank lokal dan sebagainya yang menjadi dasar bagi semua kegiatan 
yang ditujukan untuk memperkuat pengawasan dan penguasaan masyarakat atas berbagai sumber yang ada, serta kemampuan masyarakat untuk mengelola sumberdaya setempat (Stanis, 2005).

Dengan konsep pemberdayaan pada masyarakat nelayan maka usaha mitigasi terutama upaya usaha mitigasi Prabencana berupa kesiapsiagaan atau upaya pemberdayaan dengan memberikan pemahaman kepada masyarakat nelayan untuk mengantisipasi bencana melalui pemberian informasi, peningkatan kesiagaan kalau terjadi bencana dapat tercapai sehingga dapat mengurangi jumlah korban akibat bencana gempa dan tsunami di wilayah pantai Barat Sumatera.

\subsection{Solusi dan Manfaat}

$\mathrm{P}$ enelitian ini diharapkan dapat memberi masukan kepada pemerintah khususnya pelaksana kebijakan penanganan bencana tentang pendekatan kearifan lokal masyarakat pesisir pantai sebagai upaya membentuk budaya mitigasi bencana di wilayah propinsi Sumatera Barat. Selama ini program mitigasi bencana yang dijalankan oleh pemerintah melalui sosialisasisosialisasi mitigasi bencana belum optimal pelaksanaannya. Dengan tingkat ekonomi dan pendidikan yang rendah pada masyarakat daerah pesisir pantai tersebut mengakibatkan sosialisasi mitigasi bencana selalu mengalami hambatan-hambatan. Oleh karena itu potensi kearifan lokal masyarakat pesisir pantai dalam upaya pembentukan budaya mitigasi bencana sangatlah penting. Dengan keberadaan penelitian tentang pendekatan potensi kearifan budaya lokal (culture local wisdom) dalam kasus penanggulangan bencana di daerah rawan bencana sangat penting dilakukan sehingga menambah kepada bahanbahan kajian ilmu Sosial, khususnya ilmu Antropologi.

\section{Metodologi}

okasi yang dijadikan wilayah penelitian adalah di Nagari Ulakan, Kecamatan Ulakan Tapakis,
Kabupaten Padang Pariaman. Lokasi ini dipilih karena berada di wilayah pesisir pantai Barat Sumatera yang tergolong kepada zona merah rawan bencana, termasuk bencana gempa dan tsunami. Penelitian ini menggunakan pendekatan penelitian kualitatif yang memusatkan perhatian pada prinsip-prinsip umum yang mendasari perwujudan satuan-satuan gejala yang ada dalam kehidupan sosial. Penelitian ini berbentuk studi kasus yang mengutamakan penelitian yang menyelidiki fenomena dan konteksnya saling terkait dan memanfaatkan banyak bukti atau informasi untuk mencari data. Dalam penelitian studi kasus, keutuhan dari objek perlu dipertahankan. Sumber data berupa data primer diperoleh langsung dari hasil pengamatan (obesrvasi), wawancara langsung dengan informan baik secara individu maupun secara kelompok. Sedangkan data sekunder diperoleh melalui studi dokumentasi dari instansi terkait dan hasil-hasil penelitian.

Penentuan sampling lokasi penelitian dilakukan dengan menggunakan teknik area probability sampling, yakni mengambil wakil dari setiap wilayah yang terdapat dalam populasi yang didasarkan pada pertimbangan ciri atau karakteristik wilayah, yaitu yang berada di daerah tepi pantai. Untuk informan dilakukan secara purposive yang bertujuan dengan mempertimbangkan tentang orang, latar peristiwa dan proses-proses sosio-cultural sesuai dengan informasi yang hendak dibutuhkan, yaitu masyarakat nelayan yang bertempat tinggal di daerah tepi pantai, dengan kriteria sebagai berikut:

1. Mata Pencaharian sebagai nelayan

2. Kondisi rumah dalam kerusakan sedang dan parah

3. Memiliki pengetahuan terhadap bencana dan penanggulangannya.

Sedangkan informan biasa adalah pejabat pemerintahan nagari dan tokohtokoh masyarakat. Teknik analisis data yang digunakan adalah analisis kualitatif komparatif dari temuan lapangan yang akan diolah dengan data yang didapat dari literatur dan akan disajikan dalam suatu karya etnografi deskriptif. 
III. Hasil dan Pembahasan

3.1 Deskripsi Nagari Ulakan,
Kecamatan Ulakan Tapakis
Kecamatan Ulakan Tapakis,
Kabupaten Padang Pariaman, Sumatera Barat. Nagari Ulakan terdiri dari 19 korong $^{2}$, yang terdiri dari korong Binuang, korongTanjung Medan, korong Koto Panjang, korong Cubadak Pl.Gadang, korong Manggopoh Dalam, korongManggopoh Ujung, korong Pasar Ulakan, korong Padang Pauh, korong Kebun Bungo Pasang, korong Kampung Koto, Kampung Galapung, korong Padang Toboh, korongSikabu, korong Seigimba Ganting, korong Lapau Kandang, korong Maransi, korong Kampung Ladang, korong Tiram Ulakan, dan korong Ganting Tangah Padang. Nagari Ulakan berbatasan sebelah Barat dengan Samudera Indonesia, sebelah Timur dengan nagari Toboh Gadang, sebelah Utara dengan nagari pauh Kambar dan sebelah Selatan dengan nagari Tapakis.

Nagari ulakan memiliki ketinggian tempat berkisar $2 \mathrm{~m}$ dari permukaan laut dengan suhu rata-rata sekitar $23^{\circ} \mathrm{C}-24^{\circ} \mathrm{C}$ dengan rata-rata curah hujan $43 \mathrm{~mm}-55$ $\mathrm{mm} /$ bulan. Wilayah ini terdiri dari dataran rendah, dengan tinggi pesisir pantai yang rendah.

Berdasarkan data monografi Nagari Ulakan tahun 2010 bahwa jumlah penduduk nagari Ulakan secara keseluruhan adalah sebanyak 13.418 jiwa, dengan jumlah 3.082 kepala keluarga, yang terdiri dari 6.634 laki-laki dan 6.784 perempuan. Jumlah korong

1 Nagari sendiri berasal dari bahasa Sansekerta, dalam bahasa Indonesia berarti kota (ibu kota), istana dan negara atau kerajaan sehingga Minangkabau nagari sering disebut dengan "republik kecil". Nagari adalah pembagian wilayah administratif di propinsi Sumatera Barat di bawah kecamatan yang dipimpin oleh seorang wali nagari.

2 Korong adalah satu kesatuan di dalam masyarakat yang tinggal di suatu daerah tertentu. Setiap jorong memiliki pemimpin yang disebut wali korong yang berada di bawah pemerintahan nagari.

yang berada di daerah pesisir sebanyak 4 buah (21\%) dan korong bukan pesisir sebanyak 15 buah (79\%), dengan jumlah penduduk pesisir dengan mata pencaharian sebagai nelayan sebanyak 586 jiwa (5\%).

Asal usul nagari Ulakan pada dasarnya berasal dari nagari Padang Pariaman yang sangat luas, mulai dari nagari Kayu Tanam sampai nagari Indarung yang masih termasuk daerah nagari Padang Pariaman, sehingga Ulakan diidentikkan dengan kata "Panjang". Nagari Ulakan dikenal masyarakat luas atas keberadaan seorang Syech (ulama besar), yakni Syech Burhanuddin yang sangat besar pengaruhnya terhadap siar agama di nagari tersebut. Dahulunya, pembukaan jalan ke daerah nagari tersebut dilakukan oleh Syech Burhanuddin sendiri.

\section{$\mathrm{M}$}

3.2 Aktivitas Masyarakat asyarakat menganut matrilineal, mengacu perempuan. Tradisi sosial yang paling unik di nagari ini adalah tradisi perkawinan dan kematian. Tradisi perkawinan adalah perempuan 'membeli' laki-laki, artinya perempuan yang membayar biaya dan mahar perkawinan. Dalam tradisi ini ada konsep uang 'hilang' dan uang 'menjemput'. Uang hilang adalah uang yang digunakan untuk mengganti pengeluaran orangtuanya dalam membesarkan anak laki-lakinya baik berupa uang atau barang seperti motor atau mobil. Penggantian uang hilang ini tergantung kepada tingkat pendidikan dan pekerjaan laki-laki tersebut, apabila tinggi pendidikannya maka semakin tinggi uang hilangnya. Untuk uang menjemput adalah uang yang dibayar ketika menjemput laki-laki saat pelaksanaan pernikahan, dengan uang menjemput berupa ringgit sebanyak 12 emas. Dalam tradisi perkawinan ini didalamnya terdapat prosesi seperti adat menurunkan pengantin perempuan dari rumah ibunya (bundo kanduang), adanya upacara mencukur rambut, "balatui badia', adat menjemput pengantin laki-laki (bagalombang duo baleh). 
Selain tradisi perkawinan, tradisi kematian di wilayah ini terbilang unik. Tradisi kematian disebut dengan istilah 'batagak adat' dengan cara 'Bejamba', yaitu masing-masing keluarga, tetangga dan kerabat dalam satu suku yang melayat membawa makanan yang kemudian ditumpuk-tumpuk menjadi sebuah gunung makanan hingga mencapai lebih kurang 2 meter. Setelah makanan menggunung, maka dilaksanakan acara berdoa (zikir) bersama, setelah itu dilakukan kegiatan membagi-bagi harta warisan, "malewang gala", upacara doa setelah 3, 7, 14, 40 dan 100 hari kematian anggota keluarga.

\section{3}

Aktivitas Masyarakat

ktivitas ekonomi perikanan yang dilakukan oleh nelayan pada umumnya dilakukan secara berkelompok tetapi ada juga yang melakukannya secara perorangan. Kegiatan tersebut sebagian besar dilakukan oleh pihak laki-laki yang berumur diatas 15 tahun. Pendapatan nelayan di nagari Ulakan berkisar antara Rp.25.000,- hingga Rp. 100.000,-. Pendapatan nelayan termasuk rendah dikarenakan sebagian besar nelayan di nagari Ulakan tersebut adalah nelayan buruh $(60 \%)$. Aktivitas penangkapan ikan pada masyarakat nelayan Nagari Ulakan, yaitu aktivitas membagan, memayang, memukat dan menjaring. Teknologi pada penangkapan ikan menjaring menggunakan peralatan jaring dan perahu. Jaring yang selalu dipergunakan oleh masyarakat nelayan Nagari Ulakan adalah yang berukuran 100-200 m. Jaring ini ada yang jahitannya halus dan kasar. Jaring yang halus ukuran matanya memiliki panjang 25-20 cm dan lebarnya kira-kira $5 \mathrm{~cm}$, sedangkan jaring yang jahitannya kasar ukuran matanya memiliki panjang 50-60 cm dan lebar $10 \mathrm{~cm}$. Untuk jahitan yang kasar adalah untuk menangkap ikan yang besar-besar seperti ikan gembolo, ikan gurigak, belatuk dan soaso, sedangkan jahitan yang halus atau rapat adalah untuk menangkap ikan yang kecil-kecil seperti ikan campu, pinangpinang, maco dan tete. Untuk menangkap ikan dengan menjaring mempergunakan sebuah perahu yang panjangnya lebih kurang $4 \mathrm{~m}$ dan lebarnya $1 \mathrm{~m}$. Perahu yang banyak digunakan oleh masyarakat nelayan Nagari Ulakan saat ini sudah banyak memakai mesin perahu/mesin tempel.

Hasil tangkapan ikan yang diperoleh langsung di bawa ke pasar tradisional Ulakan dan disana sudah ada agen atau pembeli yang menanti. Biasanya agen-agen tersebut telah ditentukan oleh induk semang. Alasan lain nelayan menjual ikan di pasar tradisional Ulakan karena semua jenis ikan dapat diterima baik besar maupun kecil, begitu juga dengan jenis-jenisnya. Biasanya masyarakat nelayan nagari Ulakan memasarkan ikan langsung ke TPI (Tempat Pelelangan Ikan), namun ada juga pembeli (konsumen) yang membeli ikan langsung ke perahu/kapal.

\subsection{Karakteristik Kebencanaan}

$\mathrm{M}$ asyarakat nagari Ulakan yang didominasi oleh budaya Minangkabau, yang mana sangat kental dengan kehidupan alam, terutama alam lautnya di daerah pesisir pantai Barat Sumatera Barat. Lokasinya yang merupakan wilayah zona merah rawan bencana yang sangat rentan terhadap bencana tsunami akibat gempa, badai, banjir dan lain sebagainya, dimana dalam satu tahun sering terjadinya bencana lebih dari sekali. Bencana yang kerap terjadi di wilayah nagari Ulakan adalah gempa bumi yang selalu terjadi setiap saat, badai laut, banjir, kemarau yang diikuti dengan kebakaran lahan di beberapa korong. Masyarakat nagari Ulakan menafsirkan bahwa bencana seperti gempa bumi dan tsunami merupakan sebuah bencana alam. Namun, untuk bencana lain seperti kebakaran, banjir, badai laut dianggap bukanlah bencana yang membahayakan. Hal ini masyarakat beranggapan bahwa bencana gempa merupakan sesuatu bencana yang baru dibandingkan bencana lainnya sehingga mereka mesti selalu waspada setiap saat.

3.5 Pengetahuan Masyarakat Pesisir Pantai Di Daerah Rawan Bencana

Dada umumnya masyarakat tahu tentang bencana dari media massa dan perbincangan antar tetangga 
atau kerabat. Khususnya tahun-tahun belakangan ini, dimana di Indonesia kerap terjadi bencana. Pemahaman tentang bencana umumnya masih sangat rendah. Sebagian besar masyarakat nagari Ulakan belum pernah mendapatkan penyuluhan apalagi pelatihan cara penyelamatan diri kalau ada bencana dan mereka pun tidak tahun daerah mana saja daerah-daerah yang rawan terhadap bencana. Berdasarkan analisis kebutuhan akan informasi kebencanaan, diperoleh bahwa tergolong sangat penting.dilakukan, baik oleh masyarakat sendiri maupun pemerintahan nagari dan pemerintah daerah/pusat. Pengetahuan tersebut berupa informasi bermacammacam gempa, indikator terjadinya bencana, penyebab bencana, daerah rawan bencana, usaha menanggulangi bencana dan kesiapsiagaan. Hal ini menunjukkan bahwa sosialisasi pengetahuan dan pelatihan tersebut perlu diberikan agar kemelekan masyarakat terhadap bencana semakin terbuka, bila mereka paham bencana melalui sumber yang benda akan lebih siap dalam menghadap bencana, baik dalam penyelematan diri, penyelamatan keluarga dan harta benda.

Pengetahuan dasar mengenai kemitigasian bencana khsusnya gempa dan tsunami ternyata sebagian besar sudah mengetahui, walaupun akumulasi pengetahuan tersebut mereka akui masih sangat sedikit. Pengetahuan tentang mitigasi secara khusus atau spesifik berhubungan dengan bencana tertentu yang banyak terjadi di daerahnya sebagian besar tidak tahu. Demikian pula tempat-tempat evakuasi bila terjadi bencana banyak yang tidak tahu. Pengetahuan itu umumnya diperoleh dari hasil obrolan dan melihat dari televisi. Kebutuhan yang tinggi akan informasi kebencanaan sesuai dengan kerawanan bencana din daerah masing-masing perlu direalisasikan dengan cepat dan menyeluruh agar resiko-resiko bencana dapat diminimalisir, apalagi kerentanan masyarakat sangat tinggai. Sosialisasi pengetahuan tersebut menurut informan dapat dilakukan melalui penataran, pelatihan, buku, gambar, pamplet dan media cetak lainnya yang ditempel di tempat strategs atau dibagikan ke tiap keluarga.

\subsection{Potensi Kearifan Budaya Lokal Masyarakat Pesisir Pantai \\ $\mathrm{M}$ asyarakat Nagari Ulakan memiliki cukup banyak potensi kearifan lokal yang berhubungan erat} dengan persoalan kebencanaan. Hasil inventarisasi kearifan budaya lokal pada lokasi penelitian adalah (1) Tradisi zikir/doa di tepi pantai dan Mesjid yang didukung oleh tradisi makan "Bejamba", (2) Keyakinan terhadap kekuatan religius makam Syech Burhanuddin, (3) Tradisi adat "Tabuik", (4) Penanaman Tanaman Cemara dan Bakau (Magrove) di sekitar pantai, (5) Keyakinan akan kondisi pantai yang dilindungi oleh batu karang sedalam 100 meter sehingga bencana tsunami tidak bisa sampai ke nagari Ulakan.

Berdasarkan potensi kearifan budaya lokal maysrakat nagari Ulakan diperoleh bahwa sebagian besar kearifan lokasl mengarah kepada keyakinan terhadap suatu religi. Sebagai suatu sistem religi, menurut Koentjaraningrat (1993), kepercayaan masyarakat terdiri dari unsur/komponen, yaitu (1) Emosi, yang menyebabkan manusia bersikap religius. Emosi adalah suatu getaran jiwa yang dapat menggerak jiwa manusia baik secara individu maupun kelompok (2). Sistem keyakinan yang mengandung segala keyakinan manusia tentang supra natural, wujud alam gaib, nilai dan norma dari kepercayaan (3) Sistem ritus dan upacara yang merupakan usaha manusia untuk mencari hubungan dengan dewadewa, supranatural atau makhlukmakhluk yang mendiami alam gaib. Ritus (upacara suci) ini menyangkut hal ibadat yang dilakukan dan ini dapat diamati, termasuk mantra, ucapan-ucapan tertentu, samadi, nyanyian, doa, pemujaan, melakukan kurban dan sebagainya. Fungsi upacara ini adalah selain untuk memperkuat keyakinannya, juga memperkuat sistem dan nilai sosial yang ada dalam masyarakat. (4) Umat dan kesatuan sosial yang menganut sistem keyakinan tersebut, seperti suku bangsa dan lain-lain. Kepercayaan masyarakat mempunyai fungsi antara lain 
1. Produktif, termasuk semua praktek ilmu gaib yang menyangkut kegiatan produksi misalnya bercocok tanam, pembuatan alat, kegiatan dalam perdagangan dan lain-lain

2. Protektif/penolak, termasuk segala praktek ilmu gaib untuk menghindari atau menolak bencana, baik bagi tumbuhan (tanaman) atau hewan dan praktek ilmu gaib untuk menyembuhkan penyakit manusia, seperti upacara tolak bala, tolak penyakit.

3. Agressif, semua perbuatan ilmu gaib yang bertujuan merugikan, menyerang, menyakiti dan membunuh Meramal, praktek meramal berdasarkan perhitungan ilmu perbintangan.

Kekuatan religi sebagai potensi besar kearifan budaya lokal masyarakat ini, yaitu keberadaan makam ulama besar Syech Burhanuddin yang dianggap diyakini masyarakat bisa menolak segala bencana sehingga ketika bencana datang, masyarakat memiliki kekuatan besar untuk mengantisipasi bencana tersebut. Masyarakat pun melakukan dengan berbagai tradisi agama, seperti berzikir (berdoa) di makam dan di tepi pantai dan melaksanakan tradisi adat (semacam upacara Tabuik) sebagai tanda bersyukur kepada Allah SWT. Selain aspek religi, masyarakat percaya dengan kondisi geografi laut yang memiliki kekuatan penghalang dari bahaya tsunami sehingga masyarakat percaya bahwa tsunami tidak akan membahayakan mereka. Hal yang menarik dari macam-macam kearifan lokal yang dimiliki masyarakat pesisir adalah bahwa mereka begitu menyadari akan betapa pentingnya sumberdaya pesisir dan laut dalam menopang kehidupan mereka. Tindakan yang bersifat destruktif terhadap kekayaan sumberdaya alam pesisir dan sistem penangkapan yang tidak ramah lingkungan hampir tidak pernah terjadi. Semacam ada rasa takut, mereka percaya jika tindakan mereka tidak sesuai dengan kehendak alam, bersifat merusak, lambat laun cepat atau lambat mereka akan mengalami resiko.
Makna lain yang dapat disimak dari kearifan lokal/tradisional yang dimiliki oleh masyarakat pesisir di lokasi penelitian yakni selalu tercipta suasana kekerabatan dan kegotong royongan diantara masyarakat nelayan. Selalu tercipta hubungan sosial yang harmonis, saling membantu, karena itu perilaku curi, bersaing yang tidak sehat dan salingmerusak perlengkapan penangkapan nelayan tidak pernah terjadi. Dengan demikkian dalam memanfaatkan sumberdaya tidaklah bersifat serakah. Semacam ada pesan moral bagi mereka bahwa mereka hanya boleh menangkap untuk kepentingan hidup mereka (konsumsi), atau dijual untuk keperluanyang lain. Penangkapan dalam jumlah yang banyak dan besarbesaran tidak terjadi. Mereka mempersepsikan kearifan lokal sebagai suatu yang dapat menata kehidupan baik antar mereka sebagai

komintas sosial maupun dengan alam sebagai komunitas ekologis. Mereka menyadari pula bahwa eksistensi kehidupan mereka tidak terlepas dari eksistensi kehidupan makhluk lain dalam bumi yang satu sama ini. Oleh karena itubagi nelayan lokal, ketaatan dan kepatuhan terhadap aturan adat, kearifan dan tradisi yang ada sangat dijunjung tinggi. Di lain pihak, masyarakat pesisir mempunyai respons yang pesimistis terhadap implementasi dan penegakan hukumhukum formal yang berlaku sekarang.

\subsection{Upaya Mitigasi Bencana Dan Penanggulangannya}

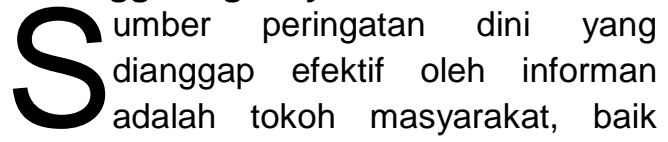
yang bersifat formal maupun non formal. Bila kepala korong dan wali nagari dimasukkan ke dalam tokoh masyarakat secara formal maka kepercayaan untuk memberikan peringatan dini dianggap paling efektif dibandingkan dengan tokoh agama, guru, pemerintah daerah, tetangga, pemerintah pusat. Ini menunjukkan memberikan kepercayaan dalam mengkooordinir masyarakat apabila terjadi nya bencana. 
Sebagian besar informan menyatakan siap berpartisipasi dalam mengatasi terjadinya bencana. Hal ini menunjukkan toleransi dan keterampilan sosial yang masih tinggi, walaupun jenis partisipasinya berbeda sesuai dengan kemampuan masing-masing.Sumbangan tenaga merupakan jenis bantuan yang paling umum yang dapat mereka berikan kalau terjadi bencana dan kemusian sumbangan dalam bentuk makanan, minuman, pakaian, pengetahuan dan swadaya masyarakat dalam mengatasi bencana yang dapat dimobilisir kapan saja kalau terjadi bencana.

\section{Kesimpulan}

i daerah penelitian, resiko bencana termasuk tinggi karena frekuensi bencana cenderung tinggi dan bervariasi. Kerentanan penduduk juga tinggi dilihat dari kedekatan dengan sumber bencana, struktur demografi yang padat dan usia non-produktif tinggi, kualitas bangunan rendah, tingkat pengetahuan dan pemahaman tentang kebencanaan rendah.

Namun demikian, dengan tingkat kerentanan yang tinggi akan bencana masyarakat mampu mengupayakan mitigasi bencana berdasarkan potensi kearifan budaya lokal masyarakat tersebut. Kekuatan religi sebagai potensi besar kearifan budaya lokal masyarakat ini, yaitu keberadaan makam ulama besar Syech Burhanuddin yang dianggap diyakini masyarakat bisa menolak segala bencana sehingga ketika bencana datang, masyarakat memiliki kekuatan besar untuk mengantisipasi bencana tersebut. Masyarakat pun melakukan dengan berbagai tradisi agama, seperti berzikir (berdoa) di makam dan di tepi pantai dan melaksanakan tradisi adat (semacam upacara Tabuik) sebagai tanda bersyukur kepada Allah SWT. Selain aspek religi, masyarakat percaya dengan kondisi geografi laut yang memiliki kekuatan penghalang dari bahaya tsunami sehingga masyarakat percaya bahwa tsunami tidak akan membahayakan mereka

\section{Ucapan Terimakasih}

Denghargaan dan terima kasih disampaikan kepada Lembaga Penelitian Universitas Andalas yang telah mendanai penelitian ini dalam program penelitian Dosen Muda untuk tahun 2011. Penulis secara khusus menyampaikan terima kasih kepada anggota penelitian dari dosen, yakni Drs. Alfitri, MS dan Drs. Zulkarnain Harun, M.Si yang telah membantu terlaksananya penelitian ini.

\section{Daftar Pustaka}

Ataupah. 2004. Peluang Pemberdayaan Keraifan Lokal Dalam Pembangunan Kehutanan. Kupang: Dephut Press.

Bappenas dengan BKNPB Jakarta. 2006. Rencana Aksi Nasional Pengurangan Risiko Bencana 2006-2009. Jakarta: Badan Perencanaan Pembangunan Nasional Press.

Bungin, Burhan, 2004, Metodologi Penelitian Kualitatif:Aktualisasi Metodologis ke Arah Ragam Varian Kontemporer, Jakarta: PT. RajaGrafindo Persada.

Danim, Sudarwan, 2002, Menjadi Peneliti Kualitatif, Bandung: Pustaka Setia.

Fauzi, H. 2006. "Memahami Fenomena Alam Pertanda Bencana". Opini dalam Banjarmasin Post, 30 September 2006. 
Kantor Cabang DKP Kec. Ulakan Tapakis.2008. Kelautan dan Perikanan.

Keraf, S. A. 2002. Etika Lingkungan. Jakarta: Pn. Buku Kompas.

Maryani, Enok. 2008. Model Sosialisasi Mitigasi Pada Masyarakat Daerah Rawan Bencana di Jawa Barat. Bandung: Penelitian HIBAH DIKTI.

Moleong, Lexy, 2001, Metode Penelitian Kualitatif, Bandung: PT.Remaja Rosda Karya.

Monografi Nagari Ulakan, Kec. Ulakan Tapakis, 2010.

Neuman, W. Lawrence, 2006, Social Research Methods: Qualitative and Quantitative Approaches $6^{\text {th }}$ Edition, US: Pearson International Edition

Noor, Muhammad dan Achmadi Jumberi. 2007. Kearifan Budaya Lokasl dalam Perspektif Pengembangan Pertanian di Lahan Rawa. Banjarbaru/Bogor: Balai Besar Sumber daya Lahan Pertanian.

Rudito, Bambang dan Melia Famiola, 2008, Social Mapping (Metode Pemetaan Sosial): Teknik Memahami Suatu Masyarakat atau Komuniti, Bandung: Rekayasa Sains.

Stanis, Stefanus. 2005. "Pengelolaan Sumberdaya Pesisir dan Laut Melalui Pemberdayaan Kearifan Lokal di Kabupaten Lembata, Propinsi Nusa Tenggara Timur". Tesis yang tidak dipublikasikan.

Sunaryo dan L. Joshi. 2003. Peranan Pengetahuan Ekologi Lokal dalam Sistem Agroforestri. World Agroforestry Centre (ICRAF) Southeast Asia Regional Offive, Bogor, Indonesia.

Wahyono, A.. 2001. Pemberdayaan Masyarakat Nelayan. Yogyakarta: Media Pressindo.

Zamzami, Lucky. 2009. "Sistem Pengetahuan Lokal nelayan Terhadap Teknologi Penangkapan Ikan pada Masyarakat Pasar Laban, Kelurahan Bungus Selatan, Kecamatan Bungus Teluk Kabung, Kota Padang" dalam Jurnal FENOMENA ISSN: 1693-4296, Volume 07, Nomor 02, September 2009, Yogyakarta: PPSH DPPM UII.

Zamzami, Lucky. 2009. "Perubahan Sosio Ekonomi dan Dampaknya Terhadap Amalan Merantau di Kalangan Nelayan di Kota Padang, Tesis UKM Malaysia yang tidak dipublikasikan.

Zamzami, Lucky. 2011. "Pemberdayaan Ekonomi Masyarakat Pesisir di Nagari Amping Perak, Sumatera Barat" dalam Jurnal MIMBAR Volume XXVII, No. 1 (Juni 2011) 1-124 ISSN 0215-8172, Bandung: Unisba 